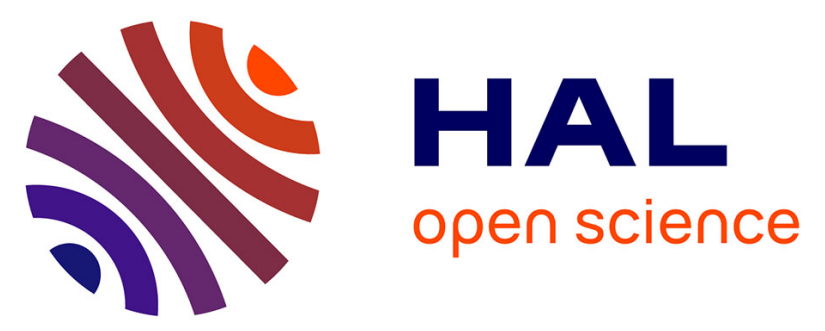

\title{
PERPHECLIM ACCAF Project perennial fruit crops and forest phenology evolution facing climatic changes.
}

Inaki Garcia de Cortazar Atauri, Jean Marc Audergon, Patrick P. Bertuzzi, Christel Anger, Marc M. Bonhomme, Isabelle Chuine, Hendrik Davi, Sylvain S. Delzon, Eric Duchêne, Jean-Michel J.-M. Legave, et al.

\section{To cite this version:}

Inaki Garcia de Cortazar Atauri, Jean Marc Audergon, Patrick P. Bertuzzi, Christel Anger, Marc M. Bonhomme, et al.. PERPHECLIM ACCAF Project perennial fruit crops and forest phenology evolution facing climatic changes.. General Assembly of the European Geosciences Union (EGU), Apr 2015, Vienne, Austria. pp.EGU2015-9846. hal-02739606

\section{HAL Id: hal-02739606 \\ https: / hal.inrae.fr/hal-02739606}

Submitted on 2 Jun 2020

HAL is a multi-disciplinary open access archive for the deposit and dissemination of scientific research documents, whether they are published or not. The documents may come from teaching and research institutions in France or abroad, or from public or private research centers.
L'archive ouverte pluridisciplinaire HAL, est destinée au dépôt et à la diffusion de documents scientifiques de niveau recherche, publiés ou non, émanant des établissements d'enseignement et de recherche français ou étrangers, des laboratoires publics ou privés. 


\section{PERPHECLIM ACCAF Project - Perennial fruit crops and forest phenology evolution facing climatic changes}

Iñaki Garcia de Cortazar-Atauri (1), Jean Marc Audergon (2), Patrick Bertuzzi (1), Christel Anger (3), Marc Bonhomme (4), Isabelle Chuine (5), Hendrik Davi (6), Sylvain Delzon (7), Eric Duchêne (8), Jean Michel Legave (9), Hélène Raynal (10), Christian Pichot (6), Cornelis Van Leeuwen (11), and Perpheclim Team (12)

(1) INRA, US 1116 AGROCLIM, F-84914 Avignon, France, (2) INRA, UR 1052 GAFL, F-84143 Avignon, France, (3) INRA, UE 0995 GBFOR, F-45075 Orleans, France, (4) INRA, UMR 0547 PIAF, F-63039 Clermont Ferrand, France, (5) CNRS, UMR 5175 CEFE, F-34293 Montpellier, France, (6) INRA, UR 0629 URFM, F-84914 Avignon, France, (7) INRA, UMR 1202 BIOGECO, F-33612 Cestas, France, (8) INRA, UMR 1131 SVQV, F-68000 Colmar, France, (9) INRA, UMR 1334 AGAP, F-34060 Montpellier, France, (10) INRA, UR 0875 MIAT, F-31326 Castanet-Tolosan, France, (11) Bordeaux Sciences Agro/INRA, UMR 1287 EGFV, F-33883 Bordeaux, France, (12) INRA

Phenology is a bio-indicator of climate evolutions. Measurements of phenological stages on perennial species provide actually significant illustrations and assessments of the impact of climate change. Phenology is also one of the main key characteristics of the capacity of adaptation of perennial species, generating questions about their consequences on plant growth and development or on fruit quality.

Predicting phenology evolution and adaptative capacities of perennial species need to override three main methodological limitations: 1) existing observations and associated databases are scattered and sometimes incomplete, rendering difficult implementation of multi-site study of genotype-environment interaction analyses; 2) there are not common protocols to observe phenological stages; 3) access to generic phenological models platforms is still very limited.

In this context, the PERPHECLIM project, which is funded by the Adapting Agriculture and Forestry to Climate Change Meta-Program (ACCAF) from INRA (French National Institute of Agronomic Research), has the objective to develop the necessary infrastructure at INRA level (observatories, information system, modeling tools) to enable partners to study the phenology of various perennial species (grapevine, fruit trees and forest trees). Currently the PERPHECLIM project involves 27 research units in France.

The main activities currently developed are: define protocols and observation forms to observe phenology for various species of interest for the project; organizing observation training; develop generic modeling solutions to simulate phenology (Phenological Modelling Platform and modelling platform solutions); support in building research projects at national and international level; develop environment/genotype observation networks for fruit trees species; develop an information system managing data and documentation concerning phenology.

Finally, PERPHECLIM project aims to build strong collaborations with public (Observatoire des Saisons) and private sector partners (technical institutes) in order to allow a more direct transfer of knowledge. 